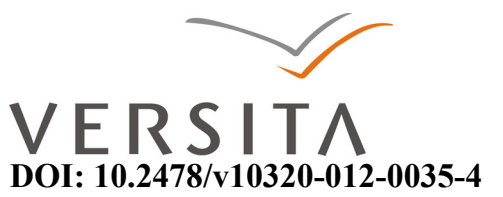

\title{
THE RENAISSANCE MIDWIFE
}

\author{
REGHINA DASCĂL \\ West University of Timişoara \\ 4, Pârvan Blvd, Timișoara, Romania \\ reghina_dascal@yahoo.co.uk
}

\begin{abstract}
The paper deals with the delineation of the subversiveness-ridden career of the midwife in history and with the specific circumstances under which this privileged hypostasis of womanhood undergoes major changes during the $17^{\text {th }}$ century. The main focus of the presentation is the female engagement with the public space during the Renaissance and the major impact of the emergent male empirical science - the scientific paradigm of New Science - upon it. The Magnetic Lady by Ben Jonson, an unduly neglected play, will provide a meaningful cultural illustration of this shift.
\end{abstract}

Keywords: female lore, midwife, misogyny, Renaissance, subversiveness

\section{Introduction}

The Renaissance in reviving the cultural models of classical antiquity constituted a backlash against the Women's Renaissance of the $12^{\text {th }}$ century. As Joan Kelly remarks, the Renaissance was a revival of the concepts and practices of classical Athens, where the domestic imprisonment of citizen wives was the norm (1984:21-22). In the High Middle Ages a refreshed onslaught on women's agency and former sites of power had already started. The classical topos of woman as gossip, as prattler, as chatterer gained new currency, with the Old Testament, classical antiquity and early patristic texts being appealed to as founts of truth. Thomas Aquinas, Alvaro Pelayo and the authors of Malleus Maleficarum are unanimous in denouncing this new scourge and calling for its suppression (Dalarun 1992:40). Aquinas sternly reminded women that they were allowed to speak only in private (in public, only prophecy was permissible, since it was the 
expression of a charismatic gift), reviving the Roman satirist Juvenal's urge that she 'who plays the critic', who 'lectures' and 'declaims' and who tries to 'seem too learn'd' is the most 'intolerable yet' (Juvenal 1906:125). Although they were the vehicle for new and progressive ideas, the Renaissance writings on education, domestic life and society map out an inferior domestic realm as opposed to a superior public realm and place severe restrictions on women's attempts to gain even a modest degree of autonomy.

Midwifery amply illustrates this shift in the social status of women. The beginnings of this hypostasis of womanhood are lost in time. The Bible contains many verses about midwifery. For example, the Egyptian midwives defied the Pharaoh's mandate to kill the Hebrews' newborn sons. Exodus 1:15-22 reads "if the midwife sees a boy on the delivery stool, he should be killed; if it is a girl, she may live." Later, in Genesis 35, Rachel recalls Joseph's birth with the midwife's help: "When she was in labour, the midwife told Rachel not to be afraid, she is having another son." Early Chinese and Hindu writings also mentioned midwives.

In all Nativity scenes there are always some women - and only women - present at the birth. In early English, the term "midwife" meant "with woman," referring to someone who supports rather than intervenes in the birth experience. In some countries, such as France, the word 'midwife' is translated as "wise woman," or sage femme.

Their presence was so natural that in the Book of James - an apocryphal gospel (St James's proto-evanghelium), in chapters 19-20 a little fable was interlarded which does not appear in the canonical gospels and which was later circulated both in mediaeval theatre and the Dominican Jacob of Voragine's Legenda Aurea. Salome the midwife insisted on personally testing the virginity of Mary. When she continued to deny evidence her arm became paralyzed being withered by fire. Only after repenting did her arm return to normal (Warner 1983:28).

\section{The paradox of midwifery as intellectual metaphor}

Since ancient times, analogies between mental creation and bodily fecundity have become commonplaces, although such rhetorical appropriations do not entail the exaltation of femaleness and are a clear sign of male authors trying to harness their anxieties about a secret female knowledge. For Philip Sidney his hectoring muse is a 
midwife and Ben Jonson - frequently delineated as the most aggressively masculine of Renaissance writers, depicts creation as a maternal function (Harvey 1992:76-115). Socrates in Theaetetus informs his interlocutor that his mother was a midwife and in pondering the nature of knowledge he explains to the young Theaetetus that he modelled his own career on his mother's profession, yet he underlines that in his case the midwifery will be applied to men, not women and he will rather tend to their soul in labour than to their bodies (Eisaman Maus 1995:186).

Intriguingly, male writers imagined their poetic and intellectual endeavour in terms of a sex to whom those endeavours were denied and subsequently they displayed a kind of rhetorical appreciation of women's bodies.

Equally baffling is the frequent reference to the womb, an organ which was supposed to chill and dampen the feminine intellect (the womb being cold and moist and migratory and subsequently accounting for the much dreaded change of moods in women who were often likened to the serpent that seeks to warm itself by entering a sleeping person's mouth). Aristotle was responsible for launching the doctrine of the excessive humidity of the female body and later misogynists built on this tradition underscoring the female association with Satan, cold as well. In the Dialogue of Placides and Timeo claimed to have been inspired by Ovid and written towards the close of the $13^{\text {th }}$ century, the Hermaphrodite is portrayed as a mythical embodiment of the thirst for sexual knowledge: he plucks out his beard, dons women's clothing, lives among women in various parts of the world. He thus earns their confidence and is given a rare access to women's mysteries. When he grows old he reverts to his masculine gender and reveals what he has learned. He has a competitor though as an initiator into the mysteries of womanhood - the Salerno midwife Trotula.

The clerical author of the tale is emulating both Hermaphrodite and Trotula in claiming to possess the secret knowledge about sexuality (Thomasset 1992:62-65). Trotula of Salerno (also known as Trotula of Ruggerio) was an eleventh-century Italian doctor (b. unknown; d. 1097) who is frequently regarded as the world's first gynecologist. Her achievements are so much more to be appreciated in a medical field dominated by men, thus setting an example for contemporary women to follow, not to mention the educational opportunities that she herself provided, at the same time 
advancing progressive ideas about women's health care. Trotula served as physician and professor at the Medical School in Salerno, Italy, the first medical school in the world. It was the only school in Europe to instruct and employ both men and women, her sons and husband being also employed there. Trotula gave her undivided attention to women's diseases and overall health and was an unmatched diagnostician in the field. She was much ahead of her time when she advocated for the use of anesthetics during labour, opposing the biblical belief of the intense suffering during childbirth as punishment for Eve's sin. Trotula's work was so influential that it set the course for the practice of women's medicine for centuries. Trotula Major on Gynecology, also known as Passionibus Mulierum Curandorum (The Diseases of Women), was a sixty-three chapter book first published in Latin in the $12^{\text {th }}$ century that remained for centuries a medical reference and even today it is regarded as the definitive sourcebook for pre-modern medical practices.

It is certainly not by chance that during the Renaissance, some scholars began to express doubt that Trotula was a woman, and others believed she was an entirely fictional character. It was supposed that a male physician Trottus had written the complex material in Trotula Major, and that Trotula was a midwife. Though scholars today believe she did, in fact, exist, there is continued research into whether Trotula's writings are solely hers or compiled from many authors.

\section{Midwifery and female power in the Renaissance}

Pregnancy, birth and all associated knowledge and practices were largely a purely female domain in the Middle Ages. Women possessed their own store of contraceptive lore, of abortifacients, the ability to practice magic (their herbalist lore) and a corresponding autonomy in sexual matters, exerting quite a lot of influence and wielding significant forms of power in their communities. They had more liberty than other women, they moved freely from their community to other provinces; they had spatial and social mobility that was often dreaded as too much power, particularly as they were called upon to act as important witnesses for rape, infanticide and bastardy. The church would license midwives because they had to perform baptism. City councils often called upon midwives to give opinions in legal cases of infanticide and abortion, to examine 
women charged with fornication or female prisoners who claimed to be pregnant in the hope of delaying their corporal punishment or execution; they served as medical assistants during epidemics and participated in the welfare system handing out food and clothes to needy women.

Generally the midwife was the senior woman in the community, commonly a married woman or widow who had herself given birth. With the gradual development of towns and cities came the specialisation of occupations, including midwifery, and with this the professional midwife emerged starting with the $14^{\text {th }}$ century (Wiesner 1998:222223). In her Complete Practice of Midwifery (1737) the West Country midwife Sarah Stone stresses how essential were her three years spent as 'deputy' to her mother to the practice of her art.

On the other hand, already in the $13^{\text {th }}$ century midwifery is dealt a heavy blow by being associated with witchcraft, exactly because of the growing influence and spreading of women's control over the medical field, what with their intimate traditional knowledge of the healing effects of plants and concoctions. According to early-modern writers like Jean Bodin, Cardano, and Della Porta, the fat of newborns was a vital ingredient in magical flying potions. Witches were also said to make candles from an infant's umbilical cord. Other byproducts of labour were also reported to have great mystical properties. The placenta was considered by some to be an aphrodisiac and, if eaten, could be used to treat infertility, a practice that the church condemned. These and other concerns regarding what the midwife-cum-witch might do with human flesh and body fluids motivated regulations in Germany (e.g. Wurzburg in 1555) that clearly specified how the midwife was to dispose of all biological bi-products during the delivery. Similarly, in France frequent laws were passed that stipulated that only women of good Catholic faith could help a birthing mother (Tucker 2003:67).

Inquisition was founded in the early $13^{\text {th }}$ century as a result of Waldensian and Catharist heretical scares and Pope Innocent VIII announced the dangers that witches posed to Christianity in a papal bull Summa desiderantes of 1484 (Karant-Nunn 1998:193). Subsequently, he asked two Dominican friars Heinrich Kramer and Jacob Sprenger to draw up a method of proceeding with such women and thus appeared the infamous Malleus Maleficarum, reprinted 14 times between 1486-1520, followed by a 
hiatus and then 16 more editions between 1576 and1669 when witch persecution was at its most intense. Whilst the earliest trials, going back to the thirteenth century, were the work of church institutions, particularly the Catholic Inquisition, the large majority of later trials saw very little formal church involvement. Within Calvinist congregations midwives could no longer administer emergency baptism and in Lutheran communities, pastors, possibly with the help of their wives, carried out a much closer oversight of midwives and their use of baptism.

Various hypotheses have been offered to explain the situation, but without doubt, the need by the male medical profession to rid the world of midwives and female folk healers cannot be overlooked (Ehrenreich and English 1973).

\section{Midwifery and new scientific paradigms}

As the sixteenth century progressed, so the new Renaissance spirit of enquiry was applied by leading surgeons to the anatomy of childbirth. Eminent among these pioneers was Ambroise Paré (1510-1590), surgeon to four French kings, notable for his use of podalic version. The fame of men like Paré, now spread through the printed word, in the vernacular rather than the traditional Latin, was to encourage male attendance in childbirth, first in 'extraordinary' cases and later in routine ones. Thus originated new designations ('Man-midwife' in English, accoucheur in French), to indicate men (usually surgeons) who added midwifery to their practice. This development gradually spread throughout Europe, being further boosted from the 1720s by the new availability of the midwifery forceps whose use, like other instruments, belonged officially to the surgeon. Meanwhile Church licensing, which had given the 'sworn' midwife her official standing, was gradually discontinued, while the higher status of leading men-midwives lifted that of all the rest, however rash and inexperienced some of them might have been.

The contrast between the erudite world of medicine against its popular feminine rival is illustrated in Christine de Pizan's Epitre d'Othea, in which both Aesculapius and the sorceress Circe appear: he a great man of science and the father of surgery (a $15^{\text {th }}$ century doctor holding a patient's urine sample in a traditional examination) and Circe cursed enchantress, an old woman in rags threading toads ingredients of her magic 
potions onto a long stick to place them into two containers - official vs. empirical medicine (Frugoni 1992:386).

Although the midwife had been central to the thesis of a serial decline in the position of women over the period since women had to progressively cede ground to the male midwife (Hufton 1997:183-184) it is a mistake to portray the midwife as a passive victim of such forceful historical and cultural developments. The use of a male midwife grew among those who could afford it in the second half of the $18^{\text {th }}$ century but the huge majority of women continued to be delivered by other women. Quaker women were much sought after and their skill as midwives became legendary (184). Undermining the misogynist myth of the incompetent midwife, historians like Hilary Marland or Helen King demonstrated that midwives were well educated, respected members of their communities but also able to handle very serious complications at delivery. Louise Bouregois (midwife to Marie de Medici, Henry IV's wife, and author of Various Observations on Sterility penned in 1609) and Jane Sharp were such prototypes of very competent midwives. The latter's Midwives Book (the first female-authored text of female midwifery published in England), appeared in 1671 and it clearly addressed an all-female audience, being written for her 'sisters, the midwives of England' (Sanders 2002:78). A Dutch woman, Catharina Schrader, left a remarkable set of memoirs recording her experience over more than 50 years of practising midwifery. She was the widow of a surgeon and she was very critical of the murderous procedures of male surgeons; she worked tirelessly at unsocial hours, performing in her career more than 4000 deliveries. Her Memoirs of the Women is dedicated to the women who gave birth, to whom she delivered either safely or not safely. She was still delivering even in her $84^{\text {th }}$ year of age, though not as frequently:

In my thirty-eight years living in Hallum in Friesland I saw my good, learned and highly esteemed, and by God and the people loved husband, go to his God to the great sadness of me and the inhabitants, leaving six small children in my thirty-eight years of age. But then it pleased God to choose me for this important work: by force almost through good doctors and the townspeople because I was at first struggling against this, because it was such a weighty affair. Also I thought that it was for me and my friends below my dignity; but finally I had myself won over. This was also the Lord's wish. [...] I sat and thought over what miracles The Lord had performed through my hands to unfortunate, distressed women in childbirth. So I decided to take up the pen in order 
to refresh once more my memory, to glorify and make great God Almighty for his great miracles bestowed on me. Not me, but You oh Lord be the honour, the glory till eternity. And also in order to alert my descendants so that they can still become educated. And I have pulled together the rare occurrences from my notes (quoted in Hufton 1997:185 ).

The intense development of print during the Renaissance did certainly bolster the male vilification of the female midwife. Les Caquets de l'Accouchee of the early $16^{\text {th }}$ century is a good case in point. The literary collection of tales, social observations and witticisms which allegedly sustained a high-born mother in her birthing room (Hufton 1997:188) was the creation of male imagination, the femaleness of this space jealously prized away from the male gaze is displayed however through the presence of the voyeuristic male narrator. Women exerted a lot of influence through official or unofficial networks such as the neighbourhood, the village, the well, the washing place, the shops, the stalls, the street exchanging information, passing on their experience (Warner 1994:33-34). The visual further intensified the effects of the printed texts: scenes of inebriation, licentious excess that followed the birth with the baby neglected and falling into the fire. (Donna C. Stanton (1993:248) remarks in this context on Bakhtin's genderblindness in his Rabelais and his World when he emphasizes the grotesque and low cultural gathering of women round the childbed - lots of food, drinking and talking contrasting all these aspects with the post-Renaissance world of private bourgeois manners).

A satirical broadsheet of 1603 entitled Tittle-Tattle or the Several Branches of Gossiping comes to reinforce such misogynistic representations: "At Child-bed when the Gossips meet,/ Fine Stories we are told:/ And if they get a Cup too much,/ Their Tongues they cannot hold./ Like wrangling Queens they fight./Then Gossips all a Warning take/Pray cease your Tongue to rattle: Go knit, and Sew, and Brew, and Bake,/And leave off tittle-tattle" (Richard West, a poet of the early $17^{\text {th }}$ century). We can plainly see illustrated here the stereotypical role of women as gossips and scandalmongers, chattering in their marketplace, water conduit, bakehouse and alehouse: "thou that at Conduits, and such other places,/The ale-house, bake-house, or the washing block/Meet daily, talking with your brazen faces, / Of peoples matters which concerne you not." 
Women's talk was always presented as sexual and scatological by male authors who attempted to re-subordinate the female claiming undivided control over the childbed to male interpretation and circulation. The disparagement of women's talk as chatter and mere gossip, a century-old stereotype further belittles the semi-professional female midwife (note the verb 'cluck' or 'cackle'). The several 'branches of gossiping' allowed the misogynist author to circumscribe all forms of the much dreaded female autonomy and women's attempts to control their own narrative to their vitriolic critique; the gossip was perceived to be a leading element in women's folly and in the sex's propensity to foment riot (etymologically the semantic evolution of gossip is revealing: 'god-sib' meaning baptismal sponsor initially, became almost exclusively female as early as the $14^{\text {th }}$ century, being applied to female friends invited by women to the christening of their child and at the end of the $16^{\text {th }}$ century the word acquired the meaning of 'midwife').

It was by such unsophisticated handling of satire that the new scientific paradigm of the New Science was used to denigrate women and disparage their role in public life or in their exertion of the role of health carers, practitioners of medicine. If women spoke the language of tradition, of myths and popular fables, men used the new discourse of experimentalism, of empiricism and inquisitiveness. The penetration of the female space of the birthing room was thus both physical and discursive (Sanders 2002:76) and the Tittle Tattle print represents a visual enactment of the marginalization of the female practice in medicine, the erosion of their prestige and social respectability: the birthing scene is consigned to the corner of the frame and the presumed privacy of the scene is in fact the object of the misogynist male gaze.

Giving birth and laying-in created a socially sanctioned space of female autonomy becoming in time a rare manifestation of its kind and it also created a site of female togetherness, exchanges and solidarity that was tightly guarded against masculine intrusion - hanging heavy curtains over windows and doors and blocking keyholes - this space exacted from the patriarchal household by women to have and rule over. The anxieties and resentment experienced by males led to the eventual reconquest of it by male doctors and by the discourse of the New Science (Sanders 2002:77). The professionalisation of medicine and medical discourse excluded women and, moreover, the masculinised medium of print disseminated the increasingly technological and 
mechanical approach to science so that the end of the $17^{\text {th }}$ century sees the space of the birthing room colonized by male experts. The masculine scientism of the age, making decisive inroads into traditional knowledge inaugurates a technological regime, a new brave world of science, hailing induction and experiment "for I admit nothing but on the faith of eyes", or at least of careful and severe examination against the myth-making power of old science. It ushers in a new position of power, that of harnessing the elements, nature and the whole universe, its over-arching goal being that of restoring man to the pre-lapsarian position (Fudge 2002:94).

When in 1616 women midwives petitioned James I to allow them to form a society, the Chamberlen brothers (Peter the Elder and the Younger, sons of William Chamberlen, a Huguenot) supported them (Peter the Elder is assumed to have invented the forceps and the brothers went to great lengths to keep the secret. When they arrived at the home of a woman in labour, two people had to carry a massive box with gilded carvings into the house. The pregnant patient was blindfolded so as not to reveal the secret, all the others had to leave the room. Then the operator went to work. The people outside heard screams, bells, and other strange noises until the cry of the baby indicated another successful delivery). In 1634 they sought to gain control of the midwives' profession for themselves, a project which failed and consequently led to a lot of resentment and that is why the forceps remained a family secret.

And yet, not all male writings on midwifery were hostile to women. Nicolas Culpeper defended traditional practice in A Directory for Midwives. He even suggests the limits to the male understanding of the female body (Sanders 2002:80), a discourse that attempts to counter the technical discourse of the male midwife hinging on the detailed anatomizing of the interior body and the practice of dissection.

\section{Ben Jonson's Magnetic Lady}

The literary representations of these important developments in the scientific and social order of the age can be exemplified in The Magnetic Lady by Ben Jonson(1632).

The play was written in 1614 and its space is domestic and thus connoted as female. Central to this female-controlled space is the midwife's conspiracy to hide a birth and protect the identity of the mother in order to secure a considerable family legacy. 
Lady Lodestone, aristocratic estate owner, has a niece called Placentia, who on her marriage is due to inherit her late parents' fortune so that her aunt tries hard to find a suitable match for her. In the meantime her greedy uncle Sir Moth Interest has the money in his care. Placentia is attended by her nurse Keep, her mother's resident advisor Polish and the latter's daughter Pleasance. Plot thickens, Placentia falls ill so that Dr Rut and the Parson Palate are called upon and they are quick to offer suggestions about the illness despite their obsession with wind and green sickness (hysterical illness befalling virgins who were not married off quickly). Polish is placed at the forefront of the attempts to cover up pregnancy as she has a vested interest in swapping her own daughter for Lodestone's niece in an attempt to prise away some of the family fortune.

What is interesting to follow in the text is Jonson's clear preference resonating with that expressed by Culpeper for women to control the birthing room.

Names are self-referential in the play and it would take at least another article to account for such references. Suffice it to mention that magnetism was often employed in the medical discourse of the time. Jane Sharp in the wake of Culperer described the reproductive act in the following terms: "The womb is that field of nature into which the seed of man and woman is cast, and it hath an attractive faculty to draw in a magnetic quality, as the lodestone draweth iron, or fire the light of the candle mand to their seed runs the woman's blood also" (quoted in Sanders 2002:85-86; emphasis mine). Placentia's name is self-referential also, her surname Steele connotative of the remedies for 'false swelling' or 'green sickness', yet she is false Steele because she is actually Polish's daughter. Equally, Dame Polish's name is indicative of her status and of her 'education': "her shee-Parasite, Her talking, soothing, sometime governing Gossip. And did bequeath her, to my care, and hand, To polish, and bring up. I moulded her. And fashion'd her, and form'd her" (Act 1, sc. 3 and 4)

On the one hand, Gossip Polish and Mother Chair ('char' and 'birthing stool') seem to be portrayed in such a way as to merely illustrate the stereotypical masculine definitions of midwives as witches and bawds: "Out though Catife witch/bawd. Beggar, gypsy: Anything indeed /But honest women". They are reprehensible characters, who slander each other and are quick to blame each other for the imminent collapse of their carefully rehearsed plot: "What will you doe? Tell truth, And shame the She-man-Divell 
in puff ' $d$ sleeves; Run any hazzard, by revealing all unto my Lady: how you chang' $d$ the cradles, And chang'd the children in 'hem. Calling your Daughter Pleasance, there Placentia, And my true Mistress by the name of Pleasance" (Act 4, sc.4).

Yet, on the other hand, Jonson despite his underlining their subversiveness never suggests any supernatural or occult power on their behalf and eventually allows female cunning and even solidarity to prevail: "Polish: Good gentle Keepe, I pray thee Mistress Nurse, Pardon my passion, I was misadvis'd. Be thou yet better, by this grave sage woman, Who is the Mother of Matrons, and great persons, And knowes the world. Come, come, be friends: and keepe these women-matters, secrets to our selves, in our owne verge" (Act 4, sc.7)

\section{Conclusion}

Jonson is neither proto-feminist nor misogynist in his play The Magnetic Lady but concerned with the reconfigurations of his own community, cultural and theatrical, and not least medical. Nevertheless he does not enthuse too much about the innovations of the New Science; on the contrary, he seems to be permanently questioning the tenets of New Science. Dr Rut, is depicted throughout the play in a most grotesque manner by Jonson who mordantly rants against his pretence at science while courting alchemy and astrology and being heavily steeped in superstition. His portrayal recalls Chaucer's physician (1.II): "And in his life a profest Voluptary; The slave of money, a Buffon in manners; Obscene in language; licentious in discourse, which he vents for wit ; Is sawcy in his Logicks, and disputing. Moreover, the female characters are often made to deliver the truth about him, as does Polish: "You are a foule mouth'd, purging, absurd Doctor ; I tell you true, and I did long to tell it you. You ha' spread a scandall i' my Ladies house here. On her sweet Neice, you never can take off With all your purges, or your plaister of Oathes; (Act 5, sc 5). There are other ample opportunities for ridiculing the demoniacal possession in the case of Needle or the pretended power of exorcism in the case of the doctor (Act 5, sc 5 and 7). As we have already mentioned above Jonson thinks highly of midwives and their prerogatives in the birthing room, allowing female solidarity to prevail in the end.

Almost 400 years later, feminist artist Judy Chicago was to pay tribute to Trotula and her legacy to professional women of all times. In her emblematic The Dinner Party 
Trotula's place setting combines references to her role as a doctor with childbirth and caretaking. The Tree of Life image in the runner gracing her place among the 39 famous women seated round the dinner table highlights Trotula's profession as a gynecologist. The Tree of Life imagery - a complex symbol of life, rejuvenation and regeneration occupies a choice place in the symbolic heritage, beginning in ancient times and continuing into Christianity. In creating the runner, Chicago chose to use the trapunto technique that can be dated back to $11^{\text {th }}$ century Sicily. The white fabric of the runner is reminiscent of swaddling clothes, and the piece itself is a quilt, creating a visual association with a baby blanket. Trotula's plate features a birthing image, as well as serpentine imagery that resembles both the caduceus, and Aesculapius' rod - an important symbol for medicine and doctors. These serpentine forms also refer us, as Judy Chicago explains, to the Aztec fertility goddess who served as the patron of midwives. Chicago chose the snake motif "because of its historical association with feminine wisdom and powers of healing" (Chicago, A Symbol of Our Heritage, 74).

\section{References}

Dalarun, J. 1992. "The Clerical Gaze” in C. Klapisch-Zuber (ed.). A History of Women in the West II. Silences of the Middle Ages. Cambridge, MA, London: Harvard University Press, pp.15-42.

Ehrenreich, B. and D. English. 1973. Witches, Midwives and Nurses: A History of Women Healers. New York: Feminist Press.

Eisaman Maus, K. 1995. Inwardness and Theater in the Renaissance. Chicago: University of Chicago Press.

Frugoni, C. 1992. "The Imagined Woman” in C. Klapisch-Zuber (ed.). A History of Women in the West II. Silences of the Middle Ages. Cambridge, MA, London: Harvard University Press, pp.336-422.

Fudge, E. 2002. "Calling Creatures by their True Names: Bacon, the New Science and the Beast in Man" in Fudge, E., R. Gilbert and S. Wiseman (eds.). At the Borders of the Human. Beasts, Bodies and Natural Philosophy in the Early Modern Period. Houndmills and New York: Palgrave, pp.91-109.

Harvey, E.D. 1992. "Ventriloquized Voices" in Feminist Theory and English Renaissance Texts. New York: Routledge, pp.76-115.

Hufton, O. 1997. The Prospect Before Her. A History of Women in Western Europe Volume I 1500-1800. London: Fontana Press. 
Jonson, B. 1914 (1640) The Magnetic Lady: Or, Humors Reconciled. New York: Henry Holt and Company [Online]. Available:

http://www.archive.org/details/magneticladyorh01jonsgoog

Juvenal. 1906. The Satires of Juvenal (Trans. A.F. Cole). London: J.M. Dent.

Karant-Nunn, S.C. 1998. "The Reformation of Women” in R. Bridenthal, S. Mosher

Stuard and M. E. Wiesner (eds.). Becoming Visible. Women in European

History Boston New York: Houghton Mifflin Company, pp.175-201.

Kelly, J. 1984. Women, History and Theory. The Essays of Joan Kelly. Chicago \&

London: The University of Chicago Press.

Sanders, J. 2002. "Midwifery and the New Science in the $17^{\text {th }}$ Century: Language, Print and the Theatre" in Fudge, E., R. Gilbert and S. Wiseman (eds.). At the Borders of the Human. Beasts, Bodies and Natural Philosophy in the Early Modern Period. Houndmills and New York: Palgrave, pp.74-90.

Stanton, D.C. 1993. "Women and the Man Behind the Screen" in J. Grantham Turner (ed.). Sexuality and Gender in Early Modern Europe: Institutions, Texts, Images. Cambridge: Cambridge University Press, pp.247-265.

Thomasset, C. 1992. "The Nature of Woman" in C. Klapisch-Zuber (ed.). A History of Women in the West II. Silences of the Middle Ages. Cambridge, MA, London: Harvard University Press, pp.43-69.

Tucker, H. 2003. Pregnant Fictions: Childbirth and the Fairy Tale in Early-Modern France. Detroit, Mich.: Wayne State University Press.

Warner, M. 1983. Alone of All Her Sex. The Myth and the Cult of the Virgin Mary. New York: Vintage Books.

Warner, M. 1994. From the Beast to the Blonde: On Fairy Tales and Their Tellers. London: Chatto\&Windus.

Wiesner, M.E. 1998. “Spinning Out Capital: Women's Work in Pre-industrial Europe, 1350-1750" in R. Bridenthal, S. Mosher Stuard and M. E. Wiesner (eds.). Becoming Visible. Women in European History Boston New York: Houghton Mifflin Company, pp.203-231.

Elizabeth A. Sackler Center for Feminist Art: The Dinner Party: Place Setting: Trotula [Online]. Available:

http://www.brooklynmuseum.org/eascfa/dinner_party/place_settings/trotula.php [2011, Oct 19].

The Office of Midwife - Some Historical Background. [Online]. Available: http://www.nursing.manchester.ac.uk/ukchnm/midwives/officeofmidwife.pdf [2011, Sept 1]. 